\title{
Influence of Particle Size and Temperature on Gasification Performance in Externally Heated Gasifier
}

\author{
Yu Feng ${ }^{1}$, Bo Xiao ${ }^{1 *}$, Klaus Goerner ${ }^{2}$, Gong Cheng ${ }^{1}$, Jingbo Wang ${ }^{1}$ \\ ${ }^{1}$ School of Environmental Science \& Engineering, Huazhong University of Science and Technology, Wuhan, China; ${ }^{2}$ Lehrstuhl fuer \\ Umweltverfahrenstechnik und Anlagentechnik, Universitaet Duisburg-Essen, Duisburg and Essen, Germany. \\ Email: xiaobo1958@126.com
}

Received March 12 ${ }^{\text {th }}, 2011$; revised April ${ }^{\text {th }}, 2011$; accepted April 12 $2^{\text {th }}, 2011$.

\begin{abstract}
In the present study the catalytic steam gasification of biomass to produce hydrogen-rich gas with calcined dolomite as catalyst in an externally heated fixed bed reactor was investigated. The influence of the reactor temperature on yield and product composition was studied at the temperature range of $700^{\circ} \mathrm{C}-900^{\circ} \mathrm{C}$. Over the ranges of experimental conditions examined, tar was completely decomposed as temperature increases from $800^{\circ} \mathrm{C}$ to $900^{\circ} \mathrm{C}$. Higher temperature resulted in more $\mathrm{H}_{2}$ and $\mathrm{CO}_{2}$ production, and dry gas yield. The highest $\mathrm{H}_{2}$ content of $51.02 \mathrm{~V} \%$, and the highest $\mathrm{H}_{2}$ yield of $1.66 \mathrm{~m}^{3} / \mathrm{kg}$ biomass were observed at the highest temperature level of $900^{\circ} \mathrm{C}$.
\end{abstract}

Keywords: Hydrogen Rich Gas, Biomass, Steam Gasification, Particle Size

\section{Introduction}

With the increase of energy consumption and escalating energy crisis, energy supply has become a particular concern around the world. So it is necessary to carefully consider that there is a need to minimize the consumption rate of non-renewable energy. The energy policy in future should be based on renewable energy, improving energy efficiency, energy conservation, relieving the contradiction between energy supply and demand, reducing environmental pollution.

As a kind of chemical material, hydrogen plays an important role in the petrochemical industry, but hydrogen will be a kind of efficient, clean and new renewable energy in the 21st century. It is estimated that humankind will enter the age of hydrogen economy in the near future. Although the hydrogen energy can't be in practical application, but it has the unique characteristics, as a clean, renewable energy, hydrogen energy will be attracted more and more attention.

Biomass is a kind of renewable resource, it is not only rich in natural but also has the low levels of ash content and sulfur content, and it will also not increase the total amount of natural carbon cycle [1-4] .

Biomass gasification is a popular technology to produce hydrogen, it uses the air or oxygen-enriched air and steam together as the gasifying agent to gasify the biomass. The product gas mainly includes hydrogen, carbon monoxide, and a small amount of non-condensable gas such as carbon dioxide, and high-molecular-weight hydrocarbons which can coagulate in normal temperature (pyrolysis oil). This pyrolysis oil is cracked to inflammable gas such as hydrogen. In the end it will become hydrogen-enriched non-condensable gas through a reforming reaction.

There are three processes included in the biomass gasification process. The catalytic conversion process, the syngas separation and purification process, and they will decide the production and quality of hydrogen.

Biomass thermal chemical gasification means that the pretreatment of biomass is heated up to $700^{\circ} \mathrm{C}$ in the medium such as air, pure oxygen, steam or the mixture of them. Then the biomass is decomposed to syngas. The main products of biomass gasification are $\mathrm{H}_{2}, \mathrm{CO}_{2}, \mathrm{CO}$ and $\mathrm{CH}_{4}$, the components vary with gasification temperature, pressure, residence time and catalyst. The choice of gasification reactors is also an important factor of deciding the components.

In the recent years, hydrogen production by biomass gasification caused the attention of the world. Researchers of overseas have done a lot of work for it, and receive 
the conclusion that nickel-based catalysts and dolomite can promote the quality of syngas [5]. Guangzhou Institute of Energy Conversion Chinese Academy of Sciences, Tsinghua University, Zhejiang University and other research institutes did some researches about it, and got good effects. Guangzhou Institute of Energy Conversion Chinese Academy of Sciences developed the new technology of biomass gasification to produce hydrogen. The innovation is that the technology connects the biomass gasification, tar catalytic cracking with steam reforming transformation [6].

\section{Experimental Section}

\subsection{Biomass Samples}

The biomass samples were pine sawdust and were collected from the furniture factory in Huazhong University of Science and Technology. The biomass samples wereshredded into particles by the crasher which was designed and manufactured by our lab, the sizes of the samples were approximately $0.15 \sim 0.6 \mathrm{~mm}$ and is shown in the Figure 1. After milling and sieving, the biomass samples were divided into four groups by particle size as follows: below $0.125 \mathrm{~mm}, 0.125$ - $0.149 \mathrm{~mm}, 0.149$ - 0.177 $\mathrm{mm}, 0.177-0.250 \mathrm{~mm}$. The crasher system is shown in the Figure 2. The proximate and ultimate analyses of biomass

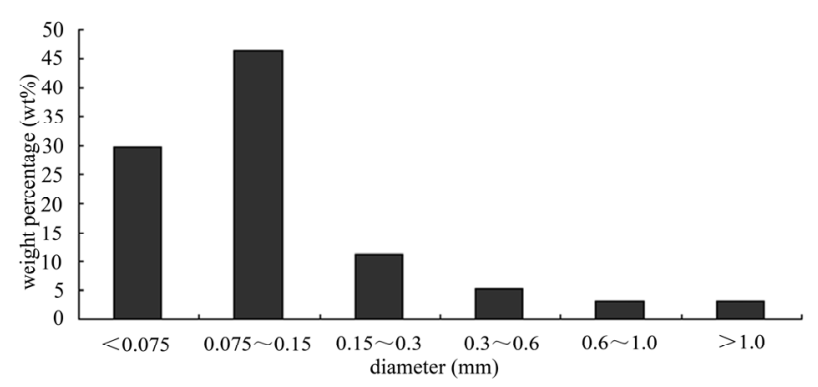

Figure 1. Biomass diameter distribution.

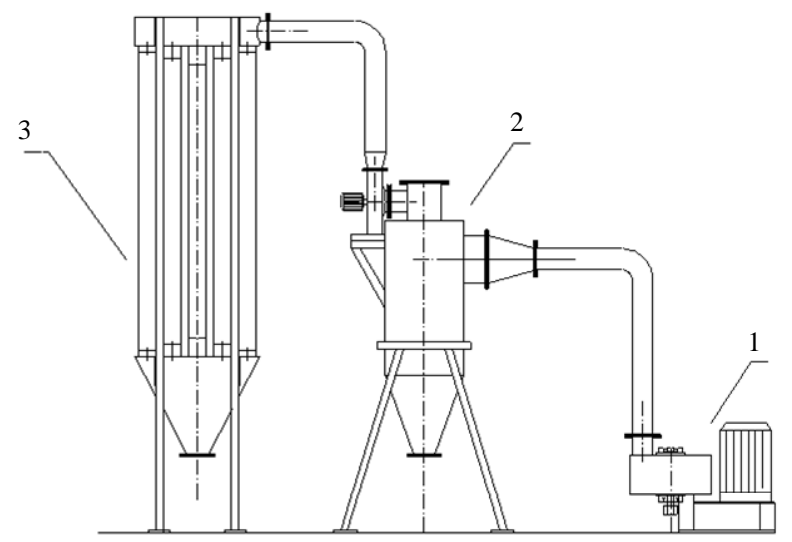

Figure 2. The crasher system. 1. crasher 2 . cyclone collector 3. bag collector). are shown in Table 1.

\subsection{Catalyst}

Generally, there are three main groups of catalysts implemented to remove tar from the producer gas $[7,8]$ : (1) natural catalysts such as dolomite and olivine; (2) alkali-based catalysts such as Li, Na, K, Rb, Cs and Fr; (3) metal-based catalyst such as nickel catalysts.

Dolomite is the most commonly used catalyst which effectively removes heavy hydrocarbons from the gas stream [8], and reduces the tar content of the effluent stream and enhancing the gas yield[9,10], because it is inexpensive and abundant. But it is significantly active only above $800^{\circ} \mathrm{C}$ [11].

Natural dolomite powder was granulated, the particle with a size of $5-10 \mathrm{~mm}$, and they were calcined in muffle oven at $900^{\circ} \mathrm{C}$ for $4 \mathrm{~h}$. Calcined dolomite was used as a catalyst in this study.

\subsection{Apparatus and Procedures}

A process flow diagram of catalytic gasification in externally heated gasifier process is shown schematically in Figure 3. In this process, the biomass gasification was conducted on a bench-scale fixed bed reactor, and used calcined dolomite as the catalyst. During the experiments, the biomass sample was continuously fed into the pyrolysis room by means of a sealing cylinder system. The catalytic gasification system consists essentially of a 0Cr25Ni20 stainless tube (i.d. $90 \mathrm{~mm}$, height $720 \mathrm{~mm}$ ), a gas cleaning section containing a cyclone solid collector and a fiber wool filter, a cooling system for the separation of water and condensable organic vapors (tar), and various gas measurement devices. The catalytic reforming room and pyrolysis room were heated by the biomass combustion in the combustion room.

In this study, the reaction temperature was controlled from $700^{\circ} \mathrm{C}$ to $900^{\circ} \mathrm{C}$ in $50^{\circ} \mathrm{C}$ increments for every group of particle size, and the operating pressure in the reactor was close to the atmospheric pressure. Prior to each test, catalyst was held in the catalytic reforming room.

The procedure for steam catalytic gasification in externally heated gasifier experiment is described below.

Table 1. Ultimate and proximate analysis of biomass char sample .

\begin{tabular}{cccc}
\hline \multicolumn{2}{c}{ Ultimate analysis } & \multicolumn{2}{c}{ Proximate analysis } \\
\hline $\mathrm{C}$ & $70.68 \mathrm{wt} \% \%$ & Volatile matter & $23.95 \mathrm{wt} . \%$ \\
$\mathrm{H}$ & $3.60 \mathrm{wt} \% \%$ & Fixed carbon & $63.72 \mathrm{wt} . \%$ \\
$\mathrm{O}^{\mathrm{b}}$ & $23.11 \mathrm{wt} \%$ & Ash & $12.33 \mathrm{wt} . \%$ \\
$\mathrm{~N}$ & $2.40 \mathrm{wt} \%$ & Low heating value & $25172 \mathrm{~kJ} / \mathrm{kg}$ \\
$\mathrm{S}$ & 0.21 wt.\% & Apparent density & $130.5 \mathrm{~kg} / \mathrm{m} 3$ \\
\hline
\end{tabular}




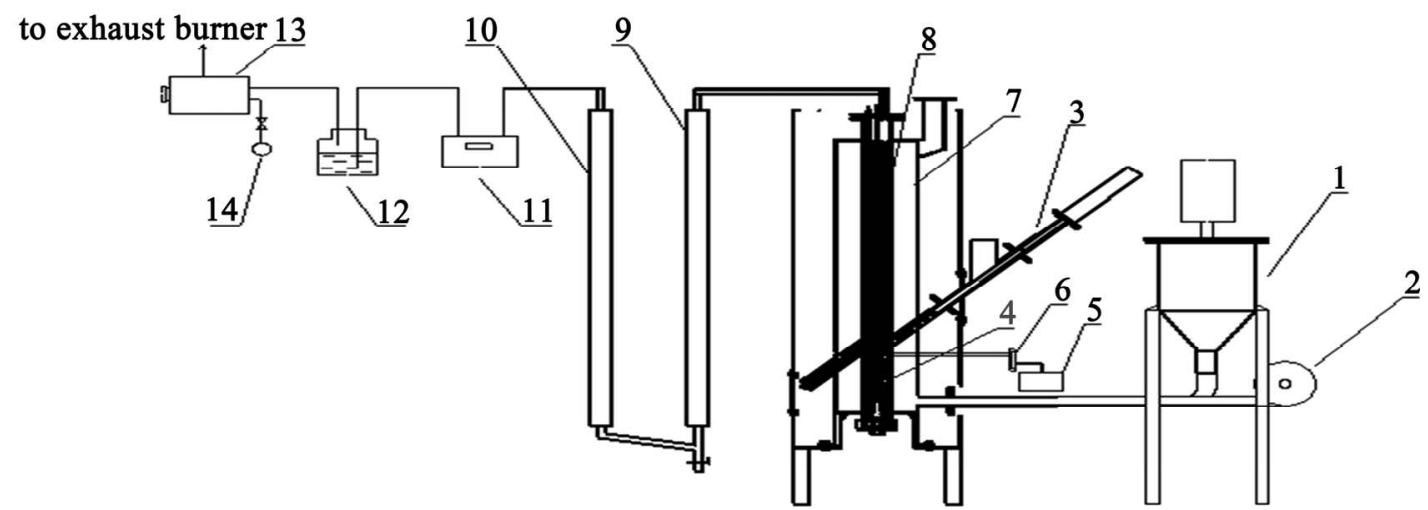

Figure 3. Flowchart of experimental apparatus. 1. churn-up system; 2. fan; 3. cylinder system; 4. pyrolysis room; 5 . steam generator; 6. steam flow meter; 7. combustion room; 8. catalytic reforming room; 9. condenser; 10. filter; 11 . gas meter; 12. silica gel; 13. air pump; 14. gas sample bag.

Prior to each experiment, calcined dolomite was filled in the catalytic reforming room. The biomass micro fuel (BMF) was blew into the pipe by fan, then it was combusted in the combustion room. When the desired temperature was reached, the biomass powder was loaded in sealing cylinder system, the biomass feedstock and steam were continuously fed into the gasifier simultaneously with the rates of steam flow rate $=0.165 \mathrm{~g} / \mathrm{min} / \mathrm{g}$ of biomass, respectively. The solid char residue was mostly collected on the bottom of the pyrolysis room, the produced gas and fine particles passed through the fiber wool filter, thereby the fine particles were removed. The condensable matter was quenched as the gas passed through the water condenser. Subsequently, the product gas was dried after entering into a gas meter and a gas dryer. At last the fan was closed and the heating was stopped, the steam generator was turned off, and the reactor was cooled to the ambient temperature.

After every experiment, the char residues collected on the on the bottom of the pyrolysis room were weighed to determine the amount unconverted solid char. The weight of liquid produced in the condenser was weighed and recorded. The gas produced was combusted after sampling and analysis. The data reported in this paper are average values of two times.

\subsection{Method of Sampling and Analysis}

The low heating value of the biomass samples was estimated using a bomb calorimeter (6300, Parr Inc.) with accuracy of $<0.15 \%$. Ultimate analysis of the biomass samples was obtained with a CHNS/O analyzer (Vario Micro cube, Elementar). Such analysis gives the weight percent of carbon, hydrogen, oxygen, nitrogen, and sulphur in the samples simultaneously. A TA Instruments system (TGA 2000, Las Navas) was used to obtain proximate analysis of the biomass samples (that is, moisture, volatile matter, fixed carbon, and ash content of the material).

X-ray diffraction (XRD) (X'Pert PRO, PANalytical B.V.) measurements of catalysts were carried out to determine main components and investigate the catalytic performance before and after the experiment. Furthermore, the surface characteristics of catalysts were determined using an accelerated surface area porosimetry (ASAP 2010, Micrometrics) instrument, which used liquid nitrogen at $77 \mathrm{~K}$, was applied to measure the BET surface area of catalyst.

The product gas volume was measured using a gas meter (J1.6-II, Wuhan Apollo), and sampled discontinuously using gas bags at regular time intervals. Gas compositions analysis was conducted with a dual channel micro-gas chromatography (Micro-GC 3000A, Agilent) that was able to provide precise analysis of the principal gas components $\left(\mathrm{H}_{2}, \mathrm{CO}, \mathrm{CO}_{2}, \mathrm{CH}_{4}, \mathrm{C}_{2} \mathrm{H}_{4}\right.$, and $\left.\mathrm{C}_{2} \mathrm{H}_{6}\right)$. The instrument was equipped with TCD and FID detectors, and the carrier gas was helium in all analyses.

\subsection{Methods of Data Processing}

The lower heating value (LHV) of hydrogen-rich gas is calculated by,

$$
\begin{aligned}
\operatorname{LHV}\left(\mathrm{MJ} / \mathrm{Nm}^{3}\right) & =\frac{1}{1000}\left(\mathrm{CO} \times 126.36+H_{2} \times 107.98\right. \\
& +\mathrm{CH}_{4} \times 358.18+\mathrm{C}_{2} \mathrm{H}_{2} \times 56.002 \\
& \left.+\mathrm{C}_{2} \mathrm{H}_{4} \times 59.036+\mathrm{C}_{2} \mathrm{H}_{6} \times 63.772\right)
\end{aligned}
$$

where, $\mathrm{CO}, \mathrm{H}_{2}, \mathrm{CH}_{4}, \mathrm{C}_{2} \mathrm{H}_{4}$, and $\mathrm{C}_{2} \mathrm{H}_{6}$ are the molar percentages of components of hydrogen-rich gas. The carbon conversion efficiency (\%) is calculated by,

$$
\begin{aligned}
& X_{C}(\%)= \\
& \frac{12 Y\left(C O \%+\mathrm{CO}_{2} \%+\mathrm{CH}_{4} \%+2 \times \mathrm{C}_{2} \mathrm{H}_{4} \%+2 \times \mathrm{C}_{2} \mathrm{H}_{6}\right)}{22.4 \times \mathrm{C} \%}
\end{aligned}
$$$$
\times 100 \%
$$ 
where, $Y$ is the dry gas yield $\left(\mathrm{Nm}^{3} / \mathrm{kg}\right)$, C\% is the mass percentage of carbon in ultimate analysis of biomass feedstock, and the other symbols are the molar percentage of components of hydrogen-rich gas.

The molecular formula of biomass can be expressed as $\mathrm{CH}_{0.611} \mathrm{O}_{0.245}$ based on the ultimate analysis (Table 1). The stoichiometric yield of $\mathrm{H}_{2}$ from biomass char is $124.67 \mathrm{~mol} \mathrm{H} / \mathrm{kg}$ biomass char calculated by the follow equations:

$$
\begin{array}{r}
\mathrm{CH}_{0.611} \mathrm{O}_{0.245}+0.755 \mathrm{H}_{2} \mathrm{O}=1.061 \mathrm{H}_{2}+\mathrm{CO} \\
\mathrm{H}_{2} \mathrm{O}+\mathrm{CO}=\mathrm{H}_{2}+\mathrm{CO}_{2}-41.2 \mathrm{MJ} / \mathrm{kmol}
\end{array}
$$

$\mathrm{H}_{2}$ potential yield is defined as the sum of measured hydrogen in product gas and the theoretical hydrogen that could be formed by completely shifting carbon monoxide as in reaction Equation (2) and completely reforming hydrocarbon species in product gas according to reaction Equation (3), given below [12]:

$$
\mathrm{C}_{n} \mathrm{H}_{m}+2 n \mathrm{H}_{2} \mathrm{O}=(2 n+(m / 2)) \mathrm{H}_{2}+n \mathrm{CO}_{2}\left(\Delta H_{298 \mathrm{~K}}>0\right)
$$

\section{Results and Discussion}

\subsection{Mechanism of Catalytic Steam Gasification of Biomass}

In general, steam gasification reactions include two steps. The first step is a thermo-chemical decomposition of biomass with production of tar, char and volatiles, this step termed primary pyrolysis, could perform at a lower temperature $\sim 300^{\circ} \mathrm{C}$, and last until a temperature of $700^{\circ} \mathrm{C}$ or even higher. The second step includes reactions of $\mathrm{CO}, \mathrm{CO}_{2}, \mathrm{H}_{2}$ and $\mathrm{H}_{2} \mathrm{O}$ with the hydrocarbon gases and carbon in biomass, thereby producing gaseous products. The catalytic steam gasification mechanism of biomass might be described by the following reactions as shown in Equations (2) - (10) [12,13] :

$$
\begin{gathered}
\mathrm{C}+\mathrm{CO}_{2} \leftrightarrow 2 \mathrm{CO}-172.6 \mathrm{MJ} / \mathrm{kmol} \\
\mathrm{C}+\mathrm{H}_{2} \mathrm{O} \rightarrow \mathrm{CO}+\mathrm{H}_{2}-131.4 \mathrm{MJ} / \mathrm{kmol} \\
\mathrm{CH}_{4}+\mathrm{H}_{2} \mathrm{O} \rightarrow \mathrm{CO}+3 \mathrm{H}_{2}+206.3 \mathrm{MJ} / \mathrm{kmol} \\
\mathrm{C}_{n} \mathrm{H}_{m}(\text { tar })+n \mathrm{H}_{2} \mathrm{O} \leftrightarrow(\mathrm{n}+\mathrm{m} / 2) \mathrm{H}_{2}+n \mathrm{CO}\left(\Delta \mathrm{H}_{298 \mathrm{~K}}>0\right) \\
C_{n} \mathrm{H}_{m}(\text { tar })+n \mathrm{CO}_{2} \leftrightarrow(\mathrm{m} / 2) \mathrm{H}_{2}+2 n \mathrm{CO}\left(\Delta H_{298 K}>0\right) \\
\mathrm{C}_{n} \mathrm{H}_{m}(\text { tar }) \\
+(n / 2+m / 4) \mathrm{O}_{2} \leftrightarrow(\mathrm{m} / 2) \mathrm{H}_{2}+n C O\left(\Delta H_{298 \mathrm{~K}}>0\right) \\
C_{n} H_{m}(\text { tar }) \leftrightarrow(\mathrm{m} / 2) H_{2}+n C\left(\Delta H_{298 \mathrm{~K}}>0\right)
\end{gathered}
$$

Calcined dolomite can accelerate the reaction rate of the steam with tar and char, also participate in the secondary reactions [14]. Furthermore, as shown in Figures 4 and 5, calcined dolomite consists of $\mathrm{CaO}$, and $\mathrm{MgO}$, which convert to $\mathrm{Ca}(\mathrm{OH})_{2}$ and $\mathrm{Mg}(\mathrm{OH})_{2}$ quickly at the presence of moisture, some $\mathrm{Ca}(\mathrm{OH})_{2}$ and $\mathrm{Mg}(\mathrm{OH})_{2}$ can convert to $\mathrm{CaCO}_{3}$ and $\mathrm{MgCO}_{3}$ using $\mathrm{CO}_{2}$ as a sorbent by reacting with $\mathrm{CO}_{2}$ produced during gasification reaction $[15,16], \mathrm{CO}_{2}$ absorbing contributes to water gas shift reaction (Equation (2)) and carbon gasification reaction (Equation (4)), which lead to production of hydrogenrich gas and high content of combustible gas.

\subsection{Influence of Particle size}

\subsubsection{Influence of Particle Size on Dry Gas Yield}

The results shown in Figure 6 that along with the increased of biomass particle size, gas production was increased. It means that with the increased of biomass particle size, the feeding rate was slower, and increased gases residence time, so the gasification progress will be more completely. But the change of gas production was not remarkable.

\subsubsection{Influence of Particle Size on Gas Composition}

During the steam gasification of biomass, reactions Equations (1)-(6) may take place simultaneously. The extent to which each reaction is involved depends on the operating conditions. So the final gas composition is the result of the combination of a series of complex and competing reactions.

The main composition of produced gases was demonstrated in Figure 7. The gases were mainly composed of $\mathrm{H}_{2}, \mathrm{CH}_{4}, \mathrm{CO}$ and $\mathrm{CO}_{2}$ at the temperature of $900^{\circ} \mathrm{C}$. When particle size varied from below 0.125 to $0.250 \mathrm{~mm}$, the contents of carbon monoxide and hydrogen obviously were decreased, while the contents of carbon dioxide and methane were increased. It means that when the particle size is decreased, the reactions are mainly controlled by pyrolysis and gasification process, and when the particle size is increased, the reactions are mainly controlled by gas diffusion process, and the size of the particle influences the gas diffusion speed. The result shows that the smaller particle size is more advantageous to production high quality gas.

\subsection{Influence of Temperature}

The gas component distribution profile from catalytic steam gasification of biomass at different reactor temperatures with calcined dolomite was shown in Table 2. It indicated that the main components are $\mathrm{H}_{2}, \mathrm{CO}, \mathrm{CO}_{2}$, $\mathrm{CH}_{4}$ and small quantities of low molecular hydrocarbons, such as $\mathrm{C}_{2} \mathrm{H}_{4}$ and $\mathrm{C}_{2} \mathrm{H}_{6}$.

Water gas shift reaction (Equation (2)) is exothermic and thus less important at higher temperature. The main reac- 


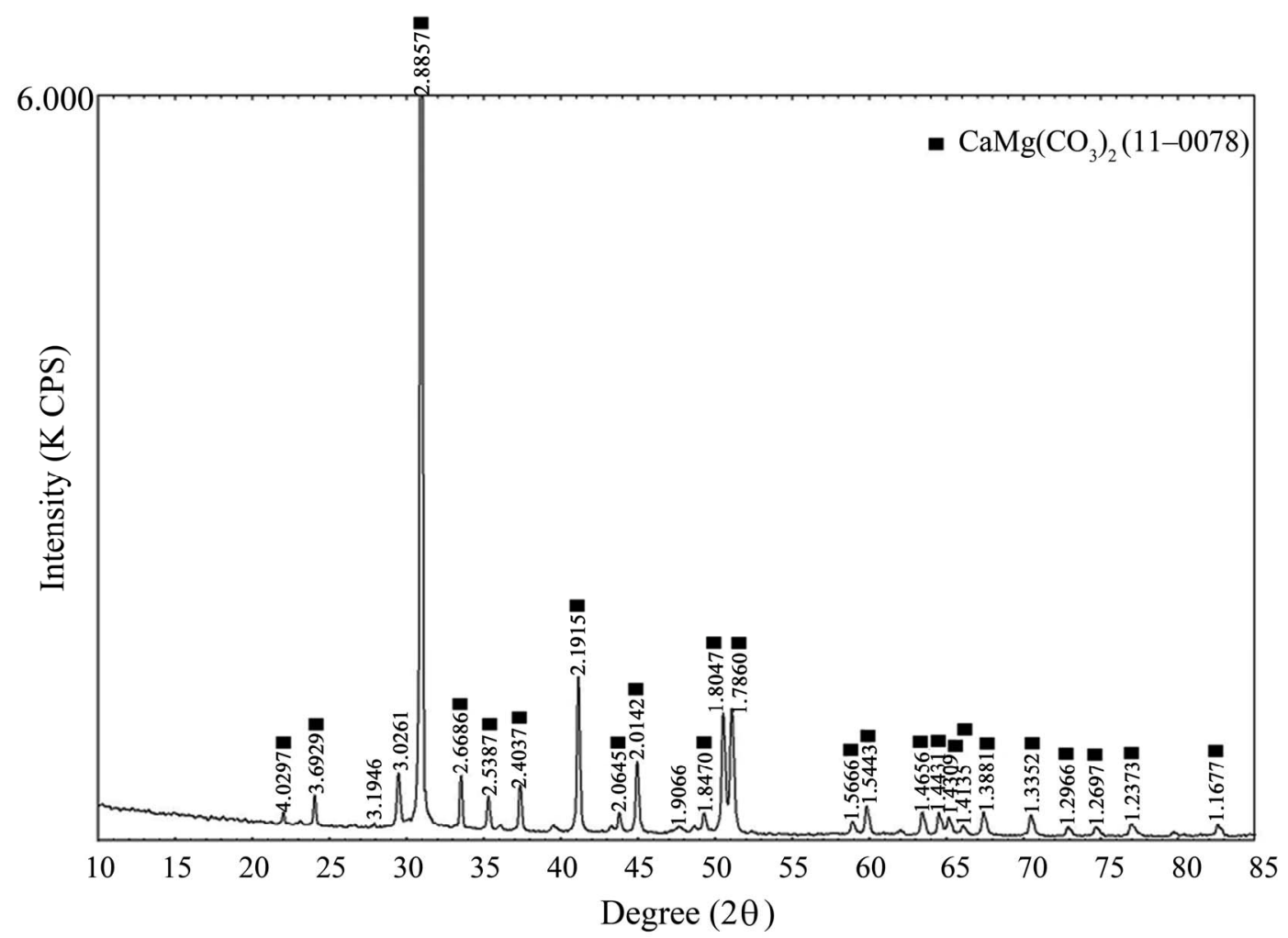

Figure 4. XRD patterns of natural dolomite.

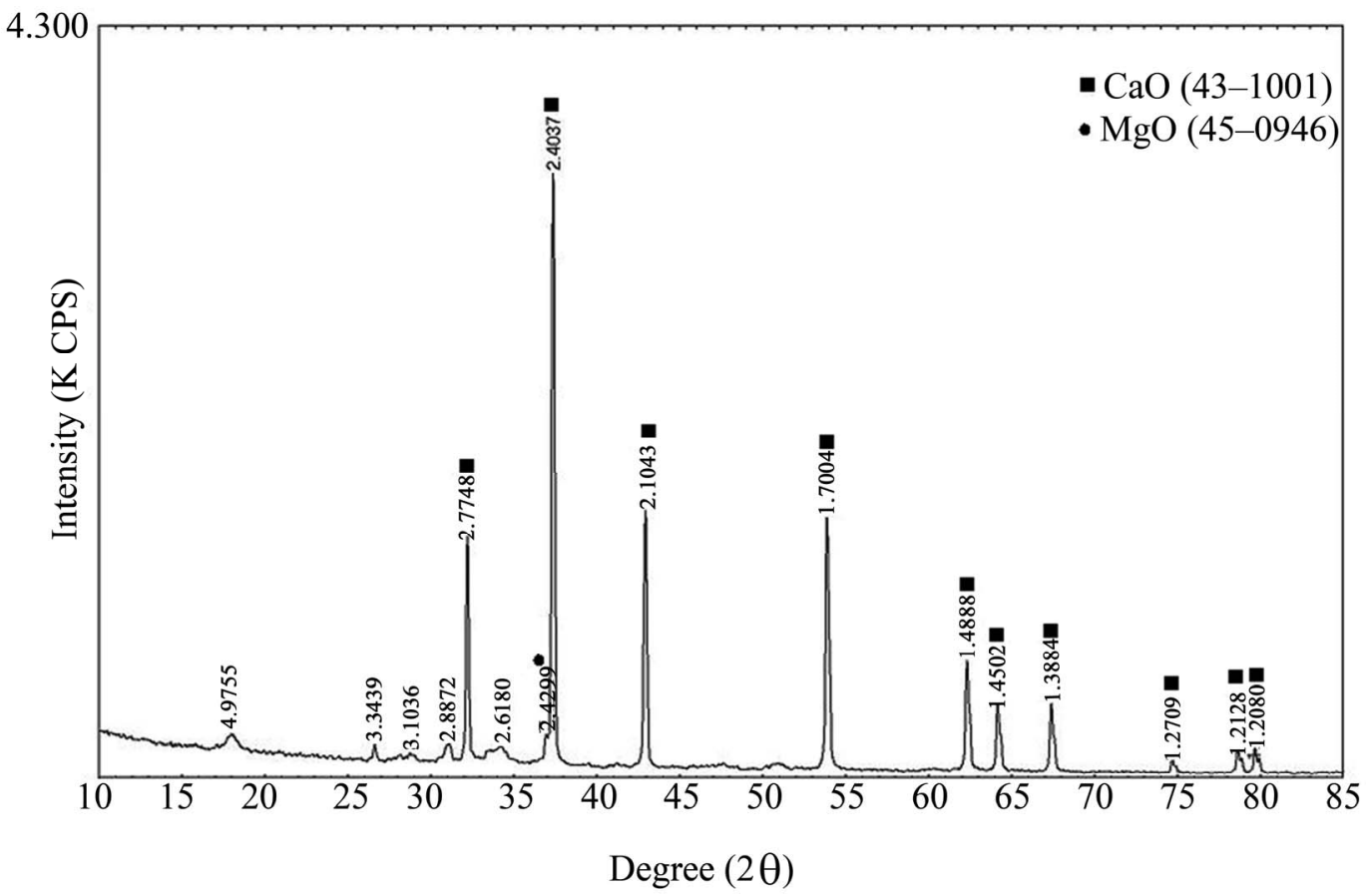

Figure 5. XRD patterns of calcined dolomite. 


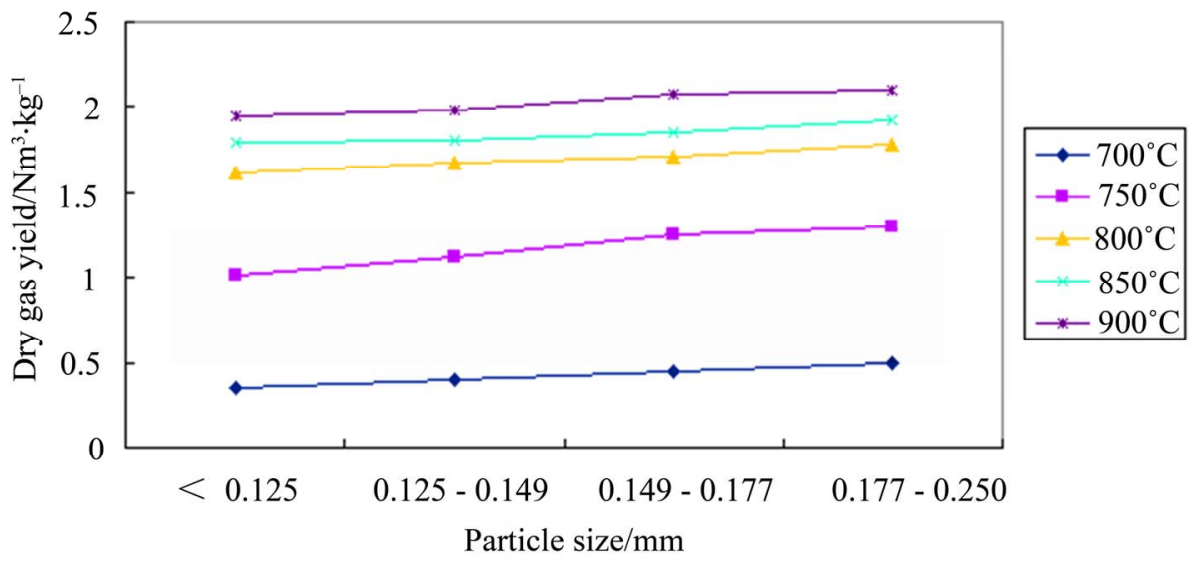

Figure 6. Influence of particle size on dry gas yield at different temperatures.

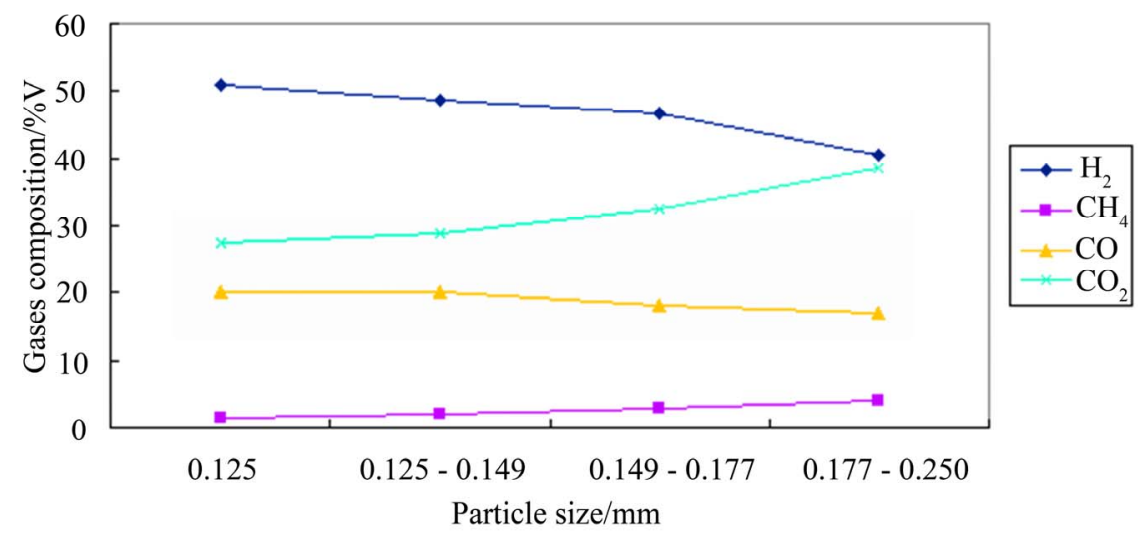

Figure 7. Influence of particle size on gas composition at temperature of ${ }^{\circ} \mathrm{C}$.

tions (Equations (2), (4) - (7)) are endothermic strengthened by increasing temperature. Therefore, the reactor temperature had a significant influence on the syngas compositions. As shown in Table 1, with temperature rising from $700^{\circ} \mathrm{C}$ to $900^{\circ} \mathrm{C}, \mathrm{H}_{2}$ content increased significantly from $23.35 \%(\mathrm{~V})$ to $51.02 \%(\mathrm{~V}), \mathrm{CO}_{2}$ content increased from $20.96 \%(\mathrm{~V})$ to $27.35 \%(\mathrm{~V})$, CO content decreased from $35.62 \%(\mathrm{~V})$ to $20.13 \%(\mathrm{~V})$, hydrogen yield increased from 0.19 to $0.83 \mathrm{~m}^{3} / \mathrm{kg}$, and LHV decreased from 20895 to $10662 \mathrm{~kJ} / \mathrm{kg}$, and the dry gas yield increased from 0.58 to $1.66 \mathrm{Nm}^{3} / \mathrm{kg}$.

It can be concluded that Boudouard reactions (Equation (4)), carbon gasification reaction (Equation (5)), together with the secondary cracking reactions of tar (Equation (7)), were the main factors responsible for the increase in $\mathrm{H}_{2}$ and $\mathrm{CO}_{2}$ contents. $\mathrm{H}_{2}$ content more than doubled from $23.35 \%(\mathrm{~V})$ to $51.02 \%(\mathrm{~V}), \mathrm{CO}_{2}$ content decreased by $6.39 \%$, while CO content decreased by $15.49 \%$, because of some CO reacting with $\mathrm{H}_{2} \mathrm{O}$. Methane decomposition (Equation (4)) was favored at higher temperature, which accounted for a significant decrease of $15.26 \%$ in $\mathrm{CH}_{4}$ content as temperature increases. $\mathrm{C}_{2} \mathrm{H}_{4}$ and $\mathrm{C}_{2} \mathrm{H}_{6}$ content were relatively small, and slightly decreased. This shown that temperature had strong influence on the decomposition of $\mathrm{CH}_{4}$, that agreed with Turn et al., higher temperature provided more favorable conditions for thermal cracking and steam reforming, so steam decomposition and dry gas yield increased. Furthermore, temperature had remarkable influence on $\mathrm{H}_{2}$ yield, $\mathrm{H}_{2}$ yield significantly increased from 0.19 to 0.83 $\mathrm{m}^{3} / \mathrm{kg}$.

Furthermore, the lower heating value (LHV) of syngas decreased from $20895 \mathrm{~kJ} / \mathrm{Nm}^{3}$ to $10662 \mathrm{~kJ} / \mathrm{Nm}^{3}$, when the reactor temperature increased from $700^{\circ} \mathrm{C}$ to $900^{\circ} \mathrm{C}$. Methane had the highest heating value in syngas, the sharp decrease of methane content led to decrease the LHV of syngas.

\section{Conclusions}

In the present work, the steam gasification of biomass using calcined dolomite as a catalyst, was performed at atmospheric pressure in externally heated gasifier over 
the temperature range of $700^{\circ} \mathrm{C}-900^{\circ} \mathrm{C}$.

The effect of particle size played a great role on the product composition and was less important for the dry gas yield. The $\mathrm{H}_{2}$ content is up to $51.02 \%(\mathrm{~V})$ when the particle is below $0.125 \mathrm{~mm}$.

Temperature also played a great role on the yield and product composition. A higher temperature resulted in a higher conversion of biomass into hydrogen-rich gas with a significant increase of $\mathrm{H}_{2}$ content from $23.35 \%$ (V) to $51.02 \%(\mathrm{~V})$. With temperature increasing from $700^{\circ} \mathrm{C}$ $900^{\circ} \mathrm{C}$, the yield of char and tar decreased while dry gas yield increased and LHV of syngas decreased.

Moreover, this paper aims to convert biomass which is essentially waste material to useful and valuable product gas such as hydrogen-rich gas.

\section{REFERENCES}

[1] J. C. Escobar, E. S. Lora, O. J. Venturini, et al., "Biofuels: Environment, Technology and Food Security," Renewable and Sustainable Energy Reviews, Vol. 13, No. 6-7, 2009, pp. 1275-1287. doi:10.1016/j.rser.2008.08.014

[2] X. T. Li, J. R. Grace, C. J. Lim, et al., "Biomass Gasification in a Circulating Fluidized Bed," Biomass and Bioenergy, Vol. 26, No. 2, 2004, pp. 171-193. doi:10.1016/S0961-9534(03)00084-9

[3] K. Maniatis and E. Millich, "Energy from Biomass and Waste: The Contribution of Utility Scale Biomass Gasification Plants,” Biomass and Bioenergy, Vol. 15, No. 3, 1998, pp. 195-200. doi:10.1016/S0961-9534(98)00052-X

[4] R. C. Saxena, D. K. Adhikari and H. B. Goyal, "Biomass-Based Energy Fuel through Biochemical Routes: A Review," Renewable and Sustainable Energy Reviews, Vol. 13, No. 1, 2009, pp. 167-178. doi:10.1016/j.rser.2007.07.011

[5] A. L. Dicks, "Dicks Hydrogen Generation from Natural Gas for the Fuel Cell Systems of Tomorrow," Journal of Power Sources, Vol. 61, No. 1-2, 1996, pp. 113-124. doi:10.1016/S0378-7753(96)02347-6

[6] L. F. Brown, “A Comparative Study of Fuels for OnBoard Hydrogen Production for Fuel-Cell-Powered Automobiles," International Journal of Hydrogen Energy, Vol. 26, No. 4, 2001, pp. 381-397. doi:10.1016/S0360-3199(00)00092-6

[7] L. Wang, C. L. Weller, D. D. Jones, et al., "Contempo- rary Issues in Thermal Gasification of Biomass and Its Application to Electricity and Fuel Production,” Biomass and Bioenergy, Vol. 32, No. 7, 2008, pp. 573-581. doi:10.1016/j.biombioe.2007.12.007

[8] P. Weerachanchai, M. Horio and C. Tangsathitkulchai, "Effects of Gasifying Conditions and Bed Materials on Fluidized Bed Steam Gasification of Wood Biomass," Bioresource Technology, Vol. 100, No. 3, 2009, pp. 14191427. doi:10.1016/j.biortech.2008.08.002

[9] X. H. Hao, L. J. Guo, X. Mao, et al., "Hydrogen Production from Glucose Used as a Model Compound of Biomass Gasified in Supercritical Water," International Journal of Hydrogen Energy, Vol. 28, No. 1, 2003, pp. 55-64. doi:10.1016/S0360-3199(02)00056-3

[10] G. Iaquaniello and A. Mangiapane, "Integration of Biomass Gasification with MCFC,” International Journal of Hydrogen Energy, Vol. 31, No. 3, 2006, pp. 399-404. doi:10.1016/j.ijhydene.2005.09.010

[11] G. Hu, S. Xu, S. Li, et al., "Steam Gasification of Apricot Stones with Olivine and Dolomite as Downstream Catalysts,” Fuel Processing Technology, Vol. 87, No. 5, 2006, pp. 375-382. doi:10.1016/j.fuproc.2005.07.008

[12] S. Turn, C. Kinoshita, Z. Zhang, et al., “An Experimental Investigation of Hydrogen Production from Biomass Gasification," International Journal of Hydrogen Energy, Vol. 23, No. 8, 1998, pp. 641-648. doi:10.1016/S0360-3199(97)00118-3

[13] A. K. Dalai, N. Batta, I. Eswaramoorthi, et al., "Gasification of Refuse Derived Fuel in a Fixed Bed Reactor for Syngas Production,” Waste Management, Vol. 29, No. 1, 2009, pp. 252-258. doi:10.1016/j.wasman.2008.02.009

[14] L. Wei, S. Xu, L. Zhang, et al., "Steam Gasification of Biomass for Hydrogen-Rich Gas in a Free-Fall Reactor," International Journal of Hydrogen Energy, Vol. 32, No. 1, 2007, pp.24-31. doi:10.1016/j.jjhydene.2006.06.002

[15] K. Gallucci, S. Stendardo and P.U. Foscolo, “ $\mathrm{CO}_{2}$ Capture by Means of Dolomite in Hydrogen Production from Syngas,” International Journal of Hydrogen Energy, Vol. 33, No. 12, 2008, pp. 3049-3055. doi:10.1016/j.ijhydene.2008.03.039

[16] M. R Mahishi and D. Y Goswami, “An Experimental Study of Hydrogen Production by Gasification of Biomass in the Presence of a CO2 Sorbent," International Journal of Hydrogen Energy, Vol. 32, No. 14, 2007, pp. 2803-2808. doi:10.1016/j.ijhydene.2007.03.030 